\title{
STRESS IN NURSING STUDENTS: AN INDONESIAN PILOT CASE STUDY
}

\section{Stres pada Mahasiswa Keperawatan: Sebuah Penelitian Pilot di Indonesia}

\author{
Imelda L.Ritonga \\ STIKES IMELDA MEDAN \\ Email: ritonga.imelda@gmail.com
}

\begin{abstract}
ABSTRAK
Pendahuluan. Penelitian-penelitian telah menemukan bahwa proses belajar di perguruan tinggi keperawatan menimbulkan stres, namun belum didapati studi yang telah dilakukan di Indonesia. Stres menyebabkan mahasiswa merasa tidak berdaya terhadap peraturan-peraturan yang ditetapkan, pasrah terhadap kondisi otoriter dan tidak berani menyuarakan pendapatnya. Penelitian ini bertujuan untuk menemukan stressor dan dampaknya pada proses belajar mahasiswa. Metode. Penelitian ini menggunakan case study dengan teori cognitive appraisal dari Lazarus dan Folkman (1984). Data dikumpulkan dengan teknik in- depth interview dengan mahasiswa. Hasil. Didapat 5 (lima) tema sebagai hasil dari penelitian ini, yakni (1). tinggal di asrama, (2). belajar di kelas, (3). belajar di klinik, (4). nilai-nilai personal dan sosial yang dipercaya, (5). efek jangka pendek dan panjang. Diskusi. Hasil yang didapat dari penelitian ini membuktikan adanya stres yang dialami oleh mahasiswa dan dampak dari stres tersebut pada hasil pembelajarannya. Sebagian masalah yang teridentifikasi merupakan hal yang spesifik untuk proses pembelajaran di perguruan tinggi keperawatan di Indonesia.
\end{abstract}

Kata kunci: stres psikologi, stressor, cognitive appraisal, koping.

\section{ABSTRACT}

Introduction. Previous studies have found that severe stress can occur in nursing students because of their education system; however there have not been any studies to address stress in nursing students, conducted in Indonesian. The studies reinforce that stress in nursing students, is an important factor for nursing lecturers to consider in nursing education. Students felt helpless when they could not change situations they did not like and complained that the learning approach was authoritarian. This study identified stressors in nursing students and effect of stress in the students' learning process. Method. A case study was used with cognitive appraisal theory from Lazarus and Folkman (1984), as the theoretical proposition. Data was collected by utilizing in-depth interviews with nursing students. Results. There were five evident themes found in this study related to stress and its effect on the students' learning process. These Themes were: (1). Dormitory living, (2). Learning in the school, (3). Learning in the clinical setting, (4). Personal and socialbeliefs, and (5). Short-term and long-term effects. Discussion. Results indicated that education process used in this particular school of nursing, created stress which impacted adversely on the students' learning process. Some of the problems identified are specific to nursing education in Indonesian.

Keywords: psychological stress, stressor, cognitive appraisal, coping

\section{INTRODUCTION}

Study in nursing is a choice after graduated from high school. In Indonesia, student can enter the nursing school as diploma or bachelor. Many families in Indonesia are still believed that become a nurse is a respected profession in the community. So, many nursing students coming to the nursing school directed from their parents. Therefore, the students do not have earlier images about nursing profession. Some of them even never had dreaming become a nurse. The phenomenon can explained to us that the students had lack of previous information about nursing when they entered the nursing school and do not have internal motivation become a nurse.
As a lecture in a nursing school, researcher found that many students had lack interest to study and participate in their learning process. Many of them also did not do well in their examination, had a lot of abstain in classes and clinics. They also ignored their paper work and had difficult behavior. The phenomenon made some questions to the researcher. What can be the reasons of the students' behavior and what can be done to the conditions?

Previous researches about stress in nursing students have identified some stressors in nursing learning process that could given some impacts in their academic performance, also to their personal beliefs and lives. Gwele 
\& Uys (1998) found that the stressors coming from the placement of clinical and classes which placed in one time. Lindop (1989) found the stressors from negative attitudes of senior nurses in clinical setting. Floyd (1991) found that nursing students had high level of depressive symptoms. Glossop (2001) found that many students left the school because of the depressive conditions. From the previous studies we can learn that learning process in nursing made particular stressors and burden to the students. And the worst things they made depressive conditions. Another interesting study from Deary, Watson and Houston (2003) with their longitudinal study had given us some hope to resolve the problem. They found that nursing students' attrition also related to the students' personality and this could made differences in their decision to stay or leave the school. The facts made some interest to the researcher to do study about stress in nursing students to find some explanations about the students' behavior in the mentioned nursing school.

\section{METHOD}

The methodology used in this research was case study regarded by Luck, Jackson and Usher (2005). In this study, the method was used to capture contemporary phenomena in nursing learning process which appraised as a stressful condition by the students. Because the study was looking for reasons and opinions, the data was collected as qualitative.

The design in this study was single holistic case study. The population was nursing students in one school. The samples for this study were students which participated voluntary after reading invitation to join the study. There were no exception criteria for the samples. And it was open for the student from first year to third year. There were 17 students registered, but only 3 students choose randomly from each year. So, there were 9 participants for the study.

Data collected by in depth interview. The data collected as cross-sectional study, it meant the data was from one point of time only. A set interview questions was used to understand about: (1). How the students managing their study, (2). Did they facing stressful condition in their learning process, (3). How they encountered the problem, (4). How the stress or problem affect to their learning process.

The students who participated in this study were representative to offer full explanation about research's problem. And by using in depth interview, researcher had flexibility in asking and redesigning the questions. All the evidence from the study was maintain in a chain of theoretical basis, so the explanation of the phenomenon from the study was based on the theory.

\section{RESULT}

There were 5 themes found from the study. The themes were: (1). dormitory living, (2).learning in school, (3).learning in clinical setting, (4).personal and social beliefs, (5). short term and long term effect. Researcher found that the condition in the four themes mentioned had given the students stressors in their learning process, and the effects were described in the latest theme. The stressors also had impacted their image in nursing professional and their expectation for their future in nursing.

Living in dormitory had given the students stressful condition because daily hassles, lack of time to study, lack of support systems, and seniority bullying. Daily hassles were from the facilities they had for their daily living, like in having food, bath or quiet time for sleep. The condition in dormitory made them had little time for their own. The condition also made them difficult to have time to study because of the number of students provided in one room. Also, they did not have their own facilities to study or fulfilled their daily needs. Sharing was made them to have big tolerance with their friends. Moreover, seniority bullying was also something disturbed their dignity. It hurt them and gave lower self esteem.

Learning in school had given the students stressful condition because uncaring lectures, to much assignment, not enough time given from their lecturer to each of them, working in group and unable to understand 
how to learn. The most stressor came from the lecturer attitude. They felt that their lecturer did not care enough to their study and how they can become a good nurse. The lecturer did not give attention to their need like enough time to consult about their problem in study, or how to do their assignment. Moreover, because of uncaring attitude from the lecturer, students were more avoided their lectures.

Learning in clinical setting had given the students stressful condition because unkind staff, no supervision, anxiety because unknown situation, more unlearning activities, long hours, lack of positive nursing model. Students felt that the clinical setting unattractive because they cannot understand how to learn in clinic. The lack of supervision in directing them to study in clinic made them feel insecure to do anything. So, the long hour in clinic only made them bored and built bad image in nursing job. The condition was worst with the attitude of the nursing staff in treating the patient and them.

Personal and social beliefs of the students also had given them stressful condition because lack of internal control, lack of role model in completing tasks, too much expectation in one period. The students' personal and social beliefs had not enough to make them believe in nursing. Many of the students were coming to nursing because of their parents' direction. They had lack previous image in nursing before coming to the school. Also, some of them never had imagination to be a nurse. These previous beliefs were getting worst when they did not get good role models in completing their tasks in nursing. They had lack internal motivation to study. They stayed in the school because their parents' expectation to them. They did not have good image in nursing profession. The motivation gave them lack ability to face problem and stress in their study. Moreover, most of the students had lack motivation to study well because their image in nursing job. They did not belief that nurses need to be professional and have abundant knowledge and abilities. The clinical setting did not well build the image in nursing professional because they cannot found the role model in clinical setting.
Short and long term effect had identified from the students were avoidance, lack of control in students accomplishment, unbearable, lack of motivation, learn hopeless and helplessness. The effects identified shown that the learning process in this particular school had failed to create love from the students to the nursing profession. The students struggle in completing their study, did not have strong beliefs in nursing, and did not build correct coping in facing the problem. The source of the problem was poor image to nursing. It started from the reason student choosed the school and worst in the process. Unfortunately, this condition will influence the students' future as they could leave the school, do not do the learning process well, do not become nurse after school or become unprofessional nurses.

\section{DISCUSSION}

What could be happen if we fail to forms our successors in nursing professional? What could be happen if nurses cannot do their responsibility as they have too? What could be happen in the community trust and respect to nurses?

The nursing students are our successors in nursing profession. As part of the profession the fact in the students' condition should be understood and solved. The theory about cognitive appraisal theory from Lazarus and Folkman (1984) used to understand the data from the interview. As shown in the schema:

\section{Causal antecedents $\longrightarrow$ Time 1..T2..T3 $\longrightarrow$ Immediate effects $\longrightarrow$ Long Time Effects}

As showed in the data we can understand that the students had lack positive image in nursing, lack of commitment in their study and low motivation to be a professional nurse in the future. We also can understand that the lecturer and nursing staff in clinical setting had influenced their norms and beliefs. Data also showed some stressors like daily hassles, assignment, and clinical work unbearable to the students and pushed them to the negative attitude. So, in the causal antecedents the problem identified were the students did not 
believe to work and study hard to be nurses, that to be good nurses were not something precious to fight for, and they had lack support from their lecturer and nursing staff who were their role model in nursing profession.

Unfortunately, the condition was not anticipated well as the students' norms were not pushed back to be more positive. So, from time to time most of the students had more negative norms in learning. They did not have strong capacity to build good coping mechanism and nevertheless, the learning process appraised as more and more stressful. Lack of ability to solve the condition with problem focus coping, made the students failed in their learning process. Unfortunately, again the condition also did not anticipated well by the students and lecturer, and the students attitude became worst and it influenced to other students. At the end, the bad attitude become unspoken culture and obstacle to the school.

What identified in the study was not new. But, by analyze the data with the schema from Cognitive Appraisal Theory we come to the root of the problem. The cause of the problem was the norms from the students to the nursing. Nursing is not something they care enough to be fight for. They cannot see the best things they can have for their life from nursing. And the problem was rooted from lack of role model in nursing they can had in their learning process. As explained by the theory as well, the norms and beliefs from human can be influenced from time to time by their cognitive appraisal. So, it is possible to form more positive norms and beliefs in the students in nursing. And based on the theory, positive norms and beliefs in nursing will push them to positive attitude in their learning process. The positive attitude will give them good knowledge about nursing profession and build their love to the profession.

The school, lecturers and nursing staff should understand their influenced to the students. What they showed in the school and clinical setting are given immediate effect to the students beliefs. It is crucial to introduce nursing as a value profession to the students. The good values in nursing profession will create positive beliefs to the nursing in the students. Lecturers are the key point in creating the students' norms. Their belief in nursing will showed in their daily opinions and behavior. It is should be aware that the lecturers' image to the nursing also transform to the students. So, if the lecturers do not have good beliefs in nursing, how can the students can have one? It is obvious that the students' attitude problem were not primarily in the students, but more to the lecturers and nursing staff as the model. It is advised to check the lecturer beliefs in nursing profession, do they have positive beliefs in nursing? As the theory showed positive beliefs will manifested in positive behavior and attitude toward the beliefs. As the data in this study pointed to the problem in the students image to the nursing, we should be aware whether the root of the problem was the lecturers' and nursing staff beliefs about nursing which influenced the image and formed the students' norms and beliefs toward nursing.

The nursing profession needs good successors to continue and build the profession to be respectful and become part of the good quality of health profession. The problem identified in nursing learning process in this particular nursing school should be anticipated. It is possible that the problem also happen in other nursing centre. This study should ringing our bell as lecturer and evaluated our beliefs in nursing. As the nursing school also should give special attention to evaluate their lecturers and clinical nursing staff whether they become good or false influenced to the students.

\section{CONCLUSION}

The students' norms, beliefs and image to nursing profession were influenced by the lecturers and nursing staff behaviors. Moreover, the image to nursing profession also influenced the students' internal motivation in completing task. The students had lack internal motivation because of lack of positive values they can built from their external environment. The condition came as unanticipated and continually become negative appraised. 


\section{RECOMMENDATION}

The strong commitment for the student accomplished their study was the Indonesian culture to obey their parents. Parents' expectation to the students' future strengthened their commitment to accomplish their study. Unfortunately, this commitment was not strong enough to push most of the students to do good learning process. It is suggested that school can amend the education process to be more supportive and pleasant environment to nurture students' morale and positive nursing model.

\section{REFERENCES}

Deary, I.J., Watson, R. \& Hogston, R. 2003. A Longitudinal Cohort Study of Burnout and Attrition in Nursing Students. Journal Adv Nursing. 43(1). Pp.71-81.

Floyd, J.A. 1991. Nursing Students' Stress Levels, Attitude Towards Drugs and
Drugs use. Archives of Psychiatric Nursing. 5(1). Pp.46-53.

Glossop, C. 2001. Student Nurses Attrition From Pre-registration Courses : Investigating Methodological Issues. Nurse Education Today.21(3). Pp.17080.

Gwele, N.S.\& Uys, L.R. 1998. Level of Stress and Academic Performance in Baccaulareate Nursing Students. Journal of Nursing Education. 37(9). Pp.404-07.

Lazarus, R.S. \& Folkman, S. 1984. Stress, Appraisal and Coping. New York: Springer Publishing Company, Inc.

Lindop, E. 1991. Individual Stress among Nurses in Training: Why Some Leave and While Others Stay? Nurse Education Toda. 11(2). Pp.110-20.

Luck, L., Jackson, D. \& Usher, K. 2006. Case Study: A Bridge Across The Paradigms. Nursing Inquiry. 13(2). Pp.103-9. 